\title{
42. Radical transformation in global supply chains: can new business models be based on biodiversity in the agrifood industry?
}

\section{Sébastien Treyer}

The food industry has been struggling for years with its impact on the environment. The impacts of input-intensive agricultural production on nature and the environment have been made obvious since the 1960s. Silent Spring by Rachel Carson from 1962 is still an extremely vivid account of the impacts of pesticides on nature, resonating with today's scientific reports on the effects on pollinators. The algae blooms in Brittany's coastal waters have been linked for a long time to a structural excess of intensive farming of pigs and chickens that has brought jobs and prosperity to a region previously suffering from underdevelopment, and emigration to other French regions. This has been well known for decades, but the trends of environment degradation have still not been reversed. One obvious explanation of the inability to change is that the downward trends in prices that farmers are being paid for their products make it nearly impossible to ask them to change their practices, because their economic viability is so close to a survival threshold. This is now all well known, and the food industry knows it must do something.

What is also well known in the public debate is that power and value are not fairly allocated along the supply chain: farmers have much less power and a small share of the value compared to upstream players (the input industry) or downstream players (processing and retailing) because their negotiation power is scattered and thus weak. That gives enormous responsibility to the large companies of the food industry: they are in power; they have the tools at hand to foster change in the whole supply chain.

The different phases of the sustainability strategy in a company like Danone are extremely interesting in this regard. In the late 2000s, this large company in the dairy industry developed a specific innovation and exploration fund, called the Livelihoods Funds, where impact investment ${ }^{1}$ projects were explored to finance sustainable agricultural practices, landscapes and food supply chains, particularly aiming at finding solutions for carbon storage and biodiversity pro- 
tection, as well as supporting smallholder farmers and food-insecure people. These explorations were significant, exploring rediversification in breeds of cattle, in sourcing strategies among a diversity of farms, in particular with regard to their size. This sometimes led to innovations that could be brought into the main business model of the company (sourcing from local smallholder livestock producers in India, for instance), but they stood in sharp contrast to the core business model at the level of the whole commercial company, driven, for instance, by the harsh competition on international milk powder markets. In such a context, massification and economies of scale seem to be a law of nature, and not an economic strategy, which makes it paradoxical to look for a business model where rediversification and destandardization would be the main motto.

However, in the early 2010 s, the orientation to sustainability in the company strategy made it manifest that diversity (of animal breeds, in agroecosystems, in the size of farms from which to source) was going to be a cornerstone of a pathway to sustainability. The tension between the existing business model and the need to rediversify at all levels of the food chain was then completely explicit.

After 2015, like other main players in the industry, Danone was faced with the need to take ambitious initiatives against climate change, and recently also for biodiversity, as well as for nutrition and food security. Barilla, for instance, took important steps towards sustainable and diversified diets, also exploring more responsible supply chains and how one of its food brands, like Wasa, could become carbon neutral. Some coalitions, like the Food and Land Use Coalition (FOLU), launched in New York in September 2019, gathered main players of the industry around commitments like stopping sourcing from deforestation and shifting to more sustainable diets. These steps taken to reduce greenhouse gas emissions are already an important challenge, and monitoring the results of this initiative is particularly crucial, to make the companies accountable for their commitments, and to learn from where they might also be facing obstacles to reaching their objectives.

On top of the carbon-neutrality challenge, the year 2019 made it very clear, with the International Science-Policy Platform on Biodiversity and Ecosystem Services (IPBES) report on the state of biodiversity degradation, that biodiversity and climate change both needed to be integrated in ambitious transformations of the business models of the food system: this sector represents one of the major drivers of biodiversity degradation, not only through land use change, but also through the homogenization, specialization and simplification of agricultural landscapes. While carbon optimization of the dairy industry would mainly lead to drastic reduction of greenhouse gas emissions through substituting animal proteins with vegetal proteins (soy milk instead of cow milk), Danone's strategy for sustainability, inspired by the Livelihoods experi- 
ence, insists a lot on biodiversity and rediversification of products, thus betting much more on grasslands and extensive ruminant production systems, than on substitution by vegetal proteins. These grasslands are crucial for biodiversity in different contexts - in particular, in Europe they can deliver important ecosystem services, including carbon storage in soils. This strategy can also lead to more economic space for smallholder livestock producers. The crucial challenge of such a strategy is that it ultimately entails deintensification or extensification, and despecialization. How would it be realistically made consistent with the current trends and state of competition in the agrifood industry? The Covid-19 health crisis might actually make this rediversification strategy more attractive, both because it could enable better prevention of pandemics linked to biodiversity degradation, and because it could reinforce the resilience of the supply chains. But the situation remains very uncertain.

This is the crude challenge that a number of players in the industry, gathered together under a coalition named One Planet Business for Biodiversity (OP2B), in New York in September 2019, are putting at the centre of the transformation towards a new business model. Of course, a business strategy based on diversification can be profitable: betting on economies of scope rather than on economies of scale, for instance. But how resilient is such a strategy in a context of always harsher competition and the race to the bottom of prices on international commodity markets like the milk market? For a smaller company or for segments of the products, the strategy could be to move upmarket, looking for a bonus on prices through a specific segment of the market. But how to carry out such a strategy to move the mainstream strategy of the whole company upmarket, without losing an important share of the consumers who are neither necessarily ready nor wealthy enough to pay for higher prices to access dairy products?

In a crucial period for biodiversity, with an important meeting of the UN Convention on Biological Diversity, its 15th conference of the parties, planned in China for early 2021, this coalition of companies has planned to come up with performance indicators that would be both realistic and ambitious, driven by the objective to rediversify their portfolio of products as well as the raw materials they source from.

We are witnessing interesting times for the agrifood industry, where business as usual will soon no longer be possible, and radically disruptive business models need to be invented. But will this really be possible? We at least need to learn from this experiment, because of the boldness of the bet that is being made. And if it happens that such transformative commitments appear to be out of reach for large companies under the pressure of their shareholders, this would then pave the way for even more radical questioning about corporate purpose. 
Maybe this is where the paradox of the quest for such a new business model needs to be connected with the prospect of making Danone a benefit corporation, so that it is not only shareholders who are the ultimate decision-makers about such strategic choices, and that social or environmental impact can be put higher in the performance evaluation of the company, at the same level as profitability. Exploring new business models to stay within planetary boundaries, both on climate change and biodiversity, might lead to a magnitude of transformation in economic strategies that the current legal status of companies cannot permit. The radical changes in business models that are needed for sustainability might necessitate evolutions in the structure of capitalism, which begins, for instance, with an evolution in the legal definition of corporate purpose, as has already been discussed in France with a view to integrating social and environmental interactions as a raison d'être in a company's statutes.

\section{NOTE}

1. Impact investing aims to generate specific beneficial social or environmental effects in addition to financial effects.

\section{REFERENCE}

IPBES (2019), Global Assessment Report on Biodiversity and Ecosystem Services of the Intergovernmental Science-Policy Platform on Biodiversity and Ecosystem Services, edited by E.S. Brondizio, J. Settele, S. Díaz and H.T. Ngo. Bonn: IPBES Secretariat. 